\title{
The Role of Wealth Taxes on Property in Poland
}

\author{
Paweł Felis \\ Correspondence: Paweł Felis, Warsaw School of Economics, Madalińskiego 6/8, 02-513 Warszawa, Poland
}

\author{
Received: July 1, 2015 Accepted: July 20, 2015 Online Published: August 12, 2015 \\ doi:10.11114/bms.v1i2.1035 \\ URL: http://dx.doi.org/10.11114/bms.v1i2.1035
}

\begin{abstract}
The article attempts to determine what may be expected from wealth taxes on property in the present Polish economy and in which circumstances. The criteria of assessment are fiscal, economic and social tax functions. The ideas included in the article are meant to contribute to a scholarly discussion on the property taxation order in certain European countries, including Poland. The conclusions from the analysis of functions of wealth taxes on property indicate the necessity for changes in the funding systems of communes in Poland. These taxes have a serious advantage over other sources due to the freedom of disposal and possibility of affecting their volume.
\end{abstract}

Keywords: local taxes, wealth taxes on property, local authorities budget

\section{Introduction-Subject Matter, Terminology and Methodological Remarks}

Local budgets own revenues constitute a special category of income. Their volume and primarily their share in the total revenue structure are treated as a peculiar litmus test of the local government financial sovereignty. An essential part of local self-government funding, according to the theory of public finance and the European Charter of Local Self-Government (1994), should come from their own revenues with regard to which self-government communities could execute their own tax policies. The theory and practice of public finance confirm the rule that the use of public funds is more effective when fund administrators and public tasks managers are closer to the community in whose favour they operate (Owsiak, 2001). The theories providing arguments for the decentralisation of the decision process and strong local government structures due to better effectiveness, responsibility, managerial skills and decision autonomy include the decentralisation theorem (Oates, 1969), the adequacy theory (Tiebout, 1956) as well as regulation principles within the "theory of public choice" (Stigler, 1957).

Therefore, public finance decentralisation processes should be followed by the strengthening of local government entities' financial independence (Kornberger-Sokołowska, 2001). This strengthening is effected for example through granting them rights with regard to the acquisition of funds. Hence, it is recommended that the significance of local taxes as local self-government instruments stimulating the social and economic development of the area should be increased (Denek, 2005).

In European countries local taxes are diversified. The dominating role is played by models in which property tax is one of the most important. A major diversifying element within the European property taxation system is the method of tax base calculation, which is related the property value or area. The area property taxation systems are applied only in a few Central and Eastern European countries, including Poland. In the case of tax calculated on the basis of property area the tax base is a combination of the floor area and land acreage. Importantly, when determining tax according to its unit value (property area unit), one generally does not consider the tax base related factors which would reflect location, market determinants and property quality. Hence, in practice, diversified tax rates are applied. Depending on the purpose, i.e. housing or business, property tax rates may differ even more than tenfold.

The article attempts to find out what may be expected from wealth taxes on property in the present Polish economy and in which circumstances. The criteria of assessment are fiscal, economic and social tax functions.

Disregarding theoretical dispute on the role of state or the scale of interference in the social and economic phenomena, it should be admitted that the idea which indicates that taxes should primarily meet fiscal functions (fiscal function superiority) is appropriate. Public authorities do not only accumulate tax revenues but also determine their titles and construction, which is closely related to the non-fiscal functions of taxation (Małecka-Ziembińska, 2012). The research of the fiscal function of wealth taxes must not omit their non-fiscal impact.

Therefore, with regard to individual functions of tax on immovable property it is necessary to: 
- consider the possibility of adjusting the volume of local tax revenue to the tasks within the competence of the local government (fiscal function);

- combine non-fiscal functions with the functions of local government goal. An opinion, supported by the practice of many EU countries, may be formulated that irrespective of the degree of decentralisation of public finance, the local government is treated as a public legal entity which should affect the social and economic development in its area. Thus, assuming that its activity is not confined to tasks within public utilities, but it consists in influencing social and economic phenomena, the resignation from the use of non-fiscal functions of wealth taxes is impossible. If local authorities are beneficiaries of wealth tax revenues, they should not be neutral with regard to the arising social needs or problems and difficulties faced by the entities within the area of the local self-government operation. However, a reservation should be made that the impact of non-fiscal functions of property taxes, due to their wealth character, is less significant than that of income taxes or consumption taxes.

Communes are the entities which are subject to analysis. In Poland they take advantage of a well-developed group of their own revenues, which, as a consequence, allows the local authorities to affect their efficiency. They include revenues from local taxes representing primarily the category of immovable property taxation in the form of property tax, agricultural tax and forestry tax.

\section{Methodology and Results}

\subsection{Fiscal Function - Fiscal Efficiency of Taxes on Immovable Property in Relation to other Components of the Commune Revenue System}

The data on commune budget revenues and their most significant own tax revenues in the years 2004-2013 are presented in Table 1. In the case of local taxes commune councils have a definite scope of tax authority defined by an act of law. The local tax authority includes the right of commune to collect taxes in favour of the local budget - the so called passive tax authority, and also to set their volume primarily through the opportunity to set tax rates (equal to or lower than the mandatory maximum rates), to introduce reliefs and exemptions - the so-called active tax authority. In the case of the latter scope of authority, communes may affect the volume of public funds used to implement tasks through the intervention in the construction of certain elements of local taxes.

Table 1. Communes budget revenues in the years 2004-2013 (in millions zlotys)

\begin{tabular}{|c|c|c|c|c|c|c|c|c|c|c|}
\hline Specification & 2004 & 2005 & 2006 & 2007 & 2008 & 2009 & 2010 & 2011 & 2012 & 2013 \\
\hline Revenues total & 72062.3 & 82083.0 & 92710.2 & 103876.5 & 111761.6 & 115209.7 & 126196.1 & 132690.5 & 139654.5 & 144260.0 \\
\hline Own revenues & 39853.3 & 46284.4 & 52257.2 & 61088.9 & 65063.2 & 63284.1 & 66547.6 & 70441.7 & 73930.5 & 78604.8 \\
\hline $\begin{array}{l}\text { Tax revenues } \\
\text { including: }\end{array}$ & 28739.4 & 31932.0 & 35507.1 & 42187.8 & 45603.9 & 44172.4 & 44648.6 & 48139.1 & 50891.5 & 53507.4 \\
\hline $\begin{array}{l}\text { Tax revenue related } \\
\text { to active tax } \\
\text { authority, (in the } \\
\text { first place taxes on } \\
\text { real property), }\end{array}$ & 12610.5 & 13434.1 & 13841.5 & 14603.7 & 15677.6 & 16451.7 & 17133.7 & 18387.7 & 20292.0 & 21563.4 \\
\hline $\begin{array}{l}\text { Tax revenues } \\
\text { related to passive } \\
\text { tax authority. }\end{array}$ & 16128.9 & 18497.9 & 21665.6 & 27584.1 & 29926.3 & 27720.7 & 27514.9 & 29751.4 & 30599.5 & 31944.0 \\
\hline
\end{tabular}

Source: author's own material based on: [Sprawozdanie z wykonania budżetu państwa].

Table 2. Commune revenues on account of tax on immovable property, their share in commune budget revenues and in GDP as well as the rate of growth in the years 2006-2013 (in millions zlotys and percentages)

\begin{tabular}{|c|c|c|c|c|c|c|c|c|}
\hline Specification & 2006 & 2007 & 2008 & 2009 & 2010 & 2011 & 2012 & 2013 \\
\hline $\begin{array}{l}\text { Revenues on account of taxes on immovable property } \\
\text { in millions zlotys }\end{array}$ & 13117.5 & 13791.1 & 14850.5 & 15611.2 & 16276.8 & 17503.3 & 19375.2 & 20622.4 \\
\hline $\begin{array}{l}\text { Share of revenues on account of taxes on immovable } \\
\text { property } \\
\text { in commune budget revenues in percentages }\end{array}$ & 14.1 & 13.3 & 13.3 & 13.6 & 12.9 & 13.2 & 13.9 & 14.3 \\
\hline $\begin{array}{l}\text { Share of revenues on account of taxes on immovable } \\
\text { property } \\
\text { in GDP in percentages }\end{array}$ & 1.2 & 1.2 & 1.2 & 1.1 & 1.1 & 1.1 & 1.2 & 1.2 \\
\hline $\begin{array}{l}\text { Share of commune budget revenues in GDP in } \\
\text { percentages }\end{array}$ & 8.7 & 8.8 & 8.7 & 8.5 & 8.8 & 8.5 & 8.6 & 8.7 \\
\hline $\begin{array}{l}\text { Rate of growth of immovable property tax payments in } \\
\text { percentages }\end{array}$ & 101.7 & 102.6 & 103.3 & 101.6 & 101.6 & 103.1 & 106.7 & 105.5 \\
\hline $\begin{array}{l}\text { Rate of growth of commune budget revenues in } \\
\text { percentages }\end{array}$ & 111.8 & 109.3 & 103.3 & 99.6 & 106.7 & 100.8 & 101.4 & 102.4 \\
\hline GDP growth rate in percentages & 106.2 & 107.2 & 103.9 & 102.6 & 103.7 & 104.8 & 101.8 & 101.7 \\
\hline
\end{tabular}


Source: author's own material based on the data in Table 1 and [Polska-wskaźniki makroekonomiczne].

Some interesting conclusions may be drawn from the analysis of statistical measures of commune finance independence (share of property tax revenues in total revenues, commune own revenues and tax revenues). Interestingly, in the examined period there was a declining significance of wealth taxes within the system of commune self-government funding, which may indicate decreasing financial independence. The deterioration of commune revenue potential due to the process of falling fiscal efficiency of local tax revenue sources is a serious threat to the implementation of social and economic tasks and goals within the system of local economy. Admittedly, since 2008 there has been a slight improvement in these relations but they are still at the significantly different level from that of 2004.

Due to the fact that from among all local taxes, wealth taxes on property play the most important role, Table 2 presents data with regard to commune revenues on this account, their share in commune budget revenues and in GDP as well as the growth rate in the years 2006-2013. Apparently, taxes on immovable property as a source of revenue have not always constituted a sufficiently stable part of communes' own revenues (on the average about $13.5 \%$ of all commune budget revenues). A slight significance of wealth taxes is confirmed by the measurement of their share in GDP (1.1 $1.2 \%)$. From among all wealth taxes on property, property tax should be regarded fiscally most significant. It provided a substantial part of funds for public tasks implementation, and in the analysed period its average share in wealth taxes amounted to over $87 \%$. Its position in commune budgets depends not only on the activities of local authorities but first of all on the adopted systemic solutions (the property tax system primarily based on property area, limited tax authority or considerable divergence in property taxes depending on the purpose). The share of property tax in commune total budget revenues during the analysed period did not change and amounted to $13 \%$. In relation to GDP, the share of this tax is also nearly linear (it fluctuated in between 1 and 1.1\%). The revenues achieved by communes on account of property tax are moderately sensitive to business cycles in economy. For example, in the period of the poor economic situation begun in 2008 commune tax revenues showed rising dynamics, except for 2011. Agricultural tax is the second largest with regard to the volume of revenue. Its share in local taxes amounts on the average to about $7 \%$. However, quoting subsequent factors, i.e. the share of revenues on account of agricultural tax in commune budget revenues (1\% share) and in GDP ( $0.1 \%$ share), there is no doubt that we are dealing with a construction of a definitely marginal fiscal significance. From among all wealth taxes, the biggest changes are connected with the revenues from agricultural tax. Revenues from this tax due to the applied solution in the area of rate setting are dependent on the prices of rye. Pegging revenues from this tax to the price of only this product led to the possibility of tax setting in relation to the atmospheric conditions or the situation on the world agricultural markets at an either exceptionally high or low level.

\subsection{Economic Function of Wealth Taxes on Property in Poland}

In order to answer the question if taxes on immovable property in Poland are an instrument of social and economic policy, it is necessary to analyse data on the value of tax preferences in local taxes. The global amount reflecting local preferences identified in local taxes came up in 2007 to about 7.7 billion zlotys ${ }^{1}$, which accounted for only nearly $0.5 \%$ of GDP. For comparison, the total value of tax preferences in state taxes amounted in 2012 to 73.8 billion zlotys, which accounted for $4.6 \%$ of GDP. In the years 2009-2012 the value of preferences in wealth taxes rose nominally by nearly $22.5 \%$. The dominating areas of support are: agriculture (36.8\% of total preferences in local taxes in 2012) and transport and environmental protection (17.7\% of total value of preferences in local taxes in 2012). The sectors which minimally benefited from the aid of local self-government are the areas of economic and social policy. In fact, there is no real opportunity to exert an impact on social and economic processes through the present solutions in the area of wealth taxes. Potential social and economic effects are in a way, a side-effect of the fiscal goal implementation.

The presented conclusions may be confirmed by the data concerning local tax policies on the basis of which it will be possible to examine the results perceived as budget effects. In the examined period the joint financial effects of the conducted tax policy nominally rose by $31 \%$, communes to a greater extent used their rights to reduce rates (a rise of over $35 \%$ ) than to apply other tools, primarily of a discretionary character (a rise of over 20\%). And for example, in 2012 the financial effects of the use of all instruments in taxes on immovable property amounted to almost 3.8 billion zlotys, of which: the reduction in rates amounted to nearly 2.8 billion zlotys $(74 \%)$ and granting reliefs, exemptions, remissions and postponements to about 1 billion zlotys (26\%). Financial losses connected with the reductions in local taxes were stable (19.5\%). The value of fiscal support does not constitute a special burden for the commune budget; its effects on the average do not exceed 3\% of the total revenues. The application of the instruments by communes consists in a conscious resignation from potential budget revenues and may contribute to the stimulation of local entrepreneurs'

\footnotetext{
1 This amount considerably differs from the value of preferences discussed later in the article. In this case, the considered tax preferences resulted either from acts of law or commune rights to conduct an autonomous tax policy. In the remaining cases tax preferences were confined to those made effective in the form of commune council resolutions.
} 
activities and attraction of foreign investors. It should be positively assessed that the value of the lost revenues due to lower local self-government tax rates is definitely higher than that due to granting other tax preferences. It indicates that communes to a greater extent apply the policy of systemic than individual support.

Table 3. The use of commune tax authority tools in the years 2008-2012

\begin{tabular}{|c|c|c|c|c|c|}
\hline Specification & 2008 & 2009 & 2010 & 2011 & 2012 \\
\hline \multicolumn{6}{|c|}{ in millions zlotys } \\
\hline Total tax preferences in tax on immovable property & 2892.5 & 3092.3 & 3113.3 & 3221.0 & 3787.6 \\
\hline Reduction in upper tax rates & 2068.1 & 2147.7 & 1978.8 & 2279.2 & 2795.7 \\
\hline Reliefs and others & 824.4 & 944.6 & 1134.5 & 941.8 & 991.9 \\
\hline \multicolumn{6}{|c|}{ in relations to revenues from taxes on immovable property in percentages } \\
\hline Total tax preferences in tax on immovable property & 19.5 & 19.8 & 19.1 & 18.4 & 19.5 \\
\hline Reduction in upper tax rates & 13.9 & 13.8 & 12.2 & 13.0 & 14.4 \\
\hline Reliefs and others & 5.6 & 6.0 & 6.9 & 5.4 & 5.1 \\
\hline
\end{tabular}

Source: author's own material based on: [Sprawozdanie z wykonania budżetu państwa].

When discussing the economic functions of taxes, it is worth pointing to the possibility of adjusting their volume to the kind of commune tasks. It is recommendable that communes should have funds adequate to the scale of public tasks accomplished by them. In the years 2008-2012 commune spending in relation to GDP initially rose from $8.9 \%$ to $9.6 \%$ (allocation function strengthened at the central level), and then slightly fell to $8.8 \%$ in 2012. It seems that the commune financial situation, and consequently the limitation of the level of implemented public tasks could be affected by the economic and financial crisis. As already mentioned, the share of taxes on immovable property in the gross domestic product is a completely different issue. No doubt that even if the tasks of the local self-government are limited, e.g. confined to the area of public utilities, wealth taxes have a moderate significance as instruments of local government tax authority.

\subsection{Social Functions of Wealth Taxes on Property in Poland}

The opponents of the present system of property taxation emphasize primarily the lack of justice when levying tax burden on tax payers possessing property, whose state and age may substantially differ. The formula of quantitative calculation of tax base does not account for the degree of amortization of property, and in this way it does not allow for the property economic diversification. For property tax collection, issues like the state of property, its value or the class of land are insignificant. However, the level of taxes is affected by the classification of land and buildings in the register as well as the way the property is used.

Building floor areas are levied with incommensurately higher taxes than land areas, which frequently leads to speculation and keeping land undeveloped in favourable locations, for example in town centres. The highest tax rates concern land and buildings used to conduct economic activity as well as buildings which meet the needs related to this activity. Maximum rates of property for housing purposes are nearly 32 -fold lower in the case of buildings twofold in the case of land than the property earmarked for business. Preferential taxation of housing property owners reduces the share of wealth tax in the total tax burden of households. Thus, it is possible to speak about a social function of taxes pursued in favour of a selected group of taxpayers. In real terms, however, what is seen here is the social injustice. The area based taxation system does not allow for the differentiation of tax levies with regard to the value of property owned by the taxpayer and the quota tax rate system adopted by the legislator does not account for the taxpayer's payment capability. Hence, owners of property of a lower market value pay the same amounts of tax dues as owners of property of a much better housing standing. All this leads to the situation that, in the case reference of tax dues calculated according to such a system of tax rates to the value of property, it is easy to notice the effect of regressiveness of property tax.

The construction of the next tax, i.e. agricultural tax approaches the principle of tax justice due to the idea of a conversion hectare, whose construction includes elements indispensable to diversify agricultural land in relation to its quality (kind and class of agricultural land, classification of a given area to one of four tax districts), not excluding the principle of efficiency. It concerns only agricultural areas exceeding 1 hectare. Thus, if the area does not exceed 1 ha, it cannot be regarded as a farm. It is still levied with an agricultural tax, however, at a higher rate. So, serious doubts may arise here with regard to the idea of social justice. Let us also emphasize that the division into two categories may lead to economically unjustified enlargement of the possessed agricultural land in order to avoid paying higher taxes.

In forestry tax, the tax base is the number of hectares, which makes kind of trees growing in the area irrelevant at all. The weakness of the current solutions consists in the disregard for the "content" of land (species of trees growing in the area), i.e. their real market value.

Assessing the implementation of the social function of taxes on property, one should account for the disproportion observed between them (Table 4). 
Table 4. Comparison of quota rates for agricultural forestry and commercial areas in the years 2008-2013

\begin{tabular}{lcccccc}
\hline \multicolumn{1}{c}{ Specification of land } & \multicolumn{7}{c}{ Rate per $1 \mathrm{~m}^{2}$ in zlotys } \\
\hline \multirow{3}{*}{ Farmland } & 2008 & 2009 & 2010 & 2011 & 2012 & 2013 \\
Other agricultural land & 0.0146 & 0.014 & 0.0085 & 0.0094 & 0.019 & 0.019 \\
Forestland & 0.0292 & 0.0279 & 0.0171 & 0.0188 & 0.0371 & 0.0379 \\
Commercial land & 0.0032 & 0.0034 & 0.003 & 0.0034 & 0.0041 & 0.0041 \\
\hline
\end{tabular}

Source: author's own material based on the data on property tax rates in the years 2008-2013 published in the Announcements of the Finance Minister and GUS data on the average rye purchase price and the average selling price of wood.

Taxes on farmland, other agricultural land and forestland are several dozen times lower than those on commercial land property, which may result from a specific mechanism of setting the tax base and taxes on farmland (monetary value equal to 2.5 quintals of rye calculated for a conversion hectare), other agricultural areas (monetary value equal to 5 quitals of rye calculated for a physical hectare), forestland (monetary value equal to $0.22 \mathrm{~m}^{3}$ calculated for a physical hectare of forest). The greatest doubt is raised with regard to the rates in agricultural tax. It turns out that in Poland the amount of tax levy is determined exclusively by the price of one of many agricultural products: rye, which is not a major product in majority of farms. Therefore, in the context of the specificity of present and future agricultural activities this solution is to be considered improper (Felis, 2015).

\section{Conclusions and Recommendations}

The formulated conclusions are to find out what may be expected from the current area based system of property taxation in Poland.

Firstly, wealth taxes are treated generally as most significant local revenues reflecting the income potential of the commune (as they possess majority of features regarded as desirable for local taxes), they do not always create a sufficiently stable part of Polish communes' own revenues. The fiscal significance of wealth taxes results primarily from the revenues from only one tax, namely the property tax, while the financial relevance of other taxes, i.e. agricultural tax and forestry tax is marginal.

Secondly, the analysed wealth taxes include, with certain exceptions, quota tax rates. The construction of tax rates adopted by the legislator results from the tax base, which in all three taxes on the possessed property is based on a differently expressed property area. The analysis of tax rates in property taxes allows for the statement that the disproportion in their volume is discernible. It concerns primarily a decisively bigger tax burden, in relation to other things levied with tax, with regard to property connected with business activity. Such an unexpected differential may give rise to well-grounded objections in the context of justice in property taxation.

Thirdly, the application of instruments through which commune authorities may affect the local development processes is pursued by means of decisions to determine the ultimate height of tax rates as well as to differentiate tax rates, exemptions and reliefs. Property tax rates are most significant from the perspective of non-fiscal functions of a property taxation system. Apparently, taxes on the possessed property have been used to pursue non-fiscal goals to a very limited extent. It results from the nature of wealth levies (they are benefits in kind, in the case of which the object of taxation is given priority) as well as the method of quantification of the tax base (area related system of property tax). The blame for the limited use of property taxation to implement non-fiscal functions should also rest with insufficiently discernible burden of tax levies, which is especially well seen in the case of agricultural and forestry taxes.

Fourthly, the assessment of solutions which are related to the budget revenue losses should take into account the efficiency of certain tax instruments in practice. The problem is becoming increasingly important when the consent of the legislator to the application of these instruments causes considerable reductions in budget revenues. In real terms, it is difficult, due to multidirectional scope of tax instruments impact, to explicitly assess the efficiency of this impact. It is important, however, for the discussed problem that the analysis of creating communes' own revenue potential and the results of application of tools of tax authority indicates that they reduced achievable revenues only insignificantly.

In conclusion, the construction defects of property taxes in Poland lead not only to the reduction in their fiscal potential but also their usefulness as an instrument to develop an efficient spatial and local development policy. As a consequence, this insufficiently efficient funding system reduces the investment activeness of communes. The conclusions from the analysis of functions performed by taxes on immovable property taxes in Poland should aim at the implementation of the target model, free of dysfunctions and negative side effects. It would be a right solution to create a single tax on property based on its value. A change in one tax must not disregard the whole tax system. Therefore, the imposition of an efficient tax on property value has to be effected together with a reduction in fiscal burden within other taxes, for example income taxes. 


\section{References}

Denek E. (2005). Podatki w gospodarce samorzadu terytorialnego w warunkach integracji europejskiej, w: Finanse, red. B. Pietrzak, SGH, Warszawa.

Europejska, K. S. L. (1994). Sporządzona w Strasburgu dnia 15 października, 124, 607.

Felis P. (2015). Agricultural tax fiscal efficiency in Poland, Management Theory and Studies for Rural Business and Infrastructure Development, 37(1).

Kornberger-Sokołowska, E. (2001). Decentralizacja finansów publicznych a samodzielność finansowa jednostek samorzadu terytorialnego, Liber, Warszawa.

Małecka-Ziembińska, E. (2012). Efektywność fiskalna podatku dochodowego od osób fizycznych w Polsce, Wydawnictwo Uniwersytetu Ekonomicznego w Poznaniu, Poznań.

Oates, W. (1969). The Effects of Property Taxes and Local Public Spending on Property Value: An Empirical Study of Tax Capitalization and Tiebaut Hypothesis, Journal of Political Economy, 77(6). http://dx.doi.org/10.1086/259584

Owsiak, S. (2001). Finanse publiczne. Teoria i praktyka, Wydawnictwo Naukowe PWN, Warszawa.

Polska - wskaźniki makroekonomiczne, Warszawa, GUS, www.stat.gov.pl.

Sprawozdanie z wykonania budżetu państwa. Informacja o wykonaniu budżetów jednostek samorzadu terytorialnego w 2004, 2005, 2006, 2007, 2008, 2009, 2010, 2011, 2012, 2013. Rada Ministrów, Warszawa.

Stigler, G. (1957). The Tenable Range of Functions of Local Government, in: Joint Economic Committee, Federal Expendditures Policy for Economic Growth and Stability., Washington, DC.

Tiebout, C. (1956). A pure theory of local expenditures, Journal of Political Economy, 64(5). http://dx.doi.org/10.1086/257839

\section{(cc) EY}

This work is licensed under a Creative Commons Attribution 3.0 License. 